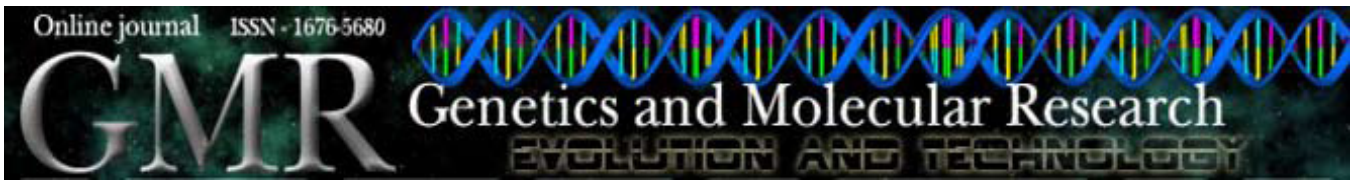

\title{
Myostatin (GDF8) single nucleotide polymorphisms in Nellore cattle
}

\author{
A.B. Grisoliaa, ${ }^{1,2}$ G.T. D’Angelo ${ }^{1}$, L.R. Porto Neto ${ }^{1}$, F. Siqueira ${ }^{3}$ and \\ J.F. Garcia ${ }^{1}$ \\ ${ }^{1}$ Departamento de Apoio, Produção e Saúde Animal, \\ Laboratório de Bioquímica e Biologia Molecular Animal, \\ Universidade Estadual Paulista, Araçatuba, SP, Brasil \\ ${ }^{2}$ Faculdade de Ciências Biológicas e Ambientais, UFGD, \\ Dourados, MS, Brasil \\ ${ }^{3}$ Embrapa Gado de Corte, Campo Grande, MS, Brasil \\ Corresponding author: A.B. Grisolia \\ E-mail: alexeiagrisolia@ufgd.edu.br
}

Genet. Mol. Res. 8 (2): 822-830 (2009)

Received October 22, 2008

Accepted May 20, 2009

Published July 21, 2009

\begin{abstract}
The myostatin gene, also known as GDF8 (growth differentiation factor 8), is located on bovine chromosome 2 (BTA2); it has three exons and two introns. Myostatin is specifically expressed during embryonic development and in adult skeletal muscle, functioning as a negative regulatory protein. Several cattle breeds (Piedmontese, Belgian Blue and Blond'Aquitaine, and others) show polymorphisms in this gene; these polymorphisms are directly related to the double muscling phenotype. We looked for polymorphisms in the Nellore cattle myostatin gene and compared them with those known for taurine breeds. Seven regions, covering the three exons of this gene, were amplified by polymerase chain reaction and sequenced, including the untranslated region. DNA from 30 adult Nellore animals was collected; DNA sequencing revealed three, seven
\end{abstract}


and four polymorphisms in exons 1,2 and 3, respectively. We found previously reported polymorphisms, as well as several new ones; for instance, 37 polymorphisms were found in the untranslated region segment, and in introns 1 and 2 there were one and three polymorphisms, respectively. The high degree of allelic heterogeneity in the myostatin gene could be related to its high mutation rate; it also could be the result of a long history of artificial selection for meat production, which has probably favored such modifications and maintained them in cattle populations. These polymorphisms identified in Nellore cattle could be useful for breeding programs.

Key words: Animal breeding; DNA sequencing; Double muscling; Meat production; Single nucleotide polymorphisms

\section{INTRODUCTION}

Myostatin or GDF8 (growth differentiation factor 8) is a member of the growth factor beta super family, also called transforming growth factor $\beta$. It acts as a negative regulatory factor of skeletal muscle mass development, by inhibiting the Myo5 and MyoD factors, which are related to the mechanisms of differentiation of precursor cells into myoblasts (McPherron and Lee, 1997).

In cattle, the myostatin gene is located at $3.1 \mathrm{cM}$ (centimorgan) from the centromeric region on chromosome 2 (BTA2), next to microsatellite TGLA44 (Charlier et al., 1995; Grobet et al., 1997; Smith et al., 1997). Molecular analysis has shown that this gene consists of three exons and two introns, with 373,374 and 381 nucleotides in each exon, and 1840 and 2033 nucleotides in each intron (Jeanplong et al., 2001). The inclusion of the untranslated region (UTR) in the third exon increases its size to 1701, 1812 or 1887 nucleotides, varying according to the positional variation of the polyadenylation sites (Jeanplong et al., 2001). The mRNA produced from the coding region of the gene codes for a protein with 375 amino acids in its final configuration (Jeanplong et al., 2001; Shibata et al., 2003).

Double muscling phenotype refers to skeletal muscle mass increase as a result of the hypertrophy or hyperplasia of the muscle fibers; it is a consequence of the myostatin gene knockout (Charlier et al., 1995; Kambadur et al., 1997; McPherron and Lee, 1997; Cappuccio et al., 1998; Grobet et al., 1997, 1998). Approximately 20 different types of polymorphisms have already been identified in the myostatin gene in different European cattle breeds, such as deletions, insertions and nucleotide substitutions (also known as single nucleotide polymorphisms - SNPs). Among the most important phenotypes related to the functional alteration of the myostatin is the one occurring in the Piedmontese breed, where the nucleotide transition $\mathrm{G} \rightarrow \mathrm{A}$ at position 938 of exon 3 determines the amino acid change of cysteine to tyrosine at position 313 (C313Y). This alteration determines the breakage of disulfide bonds, due to the absence of cysteine in the carboxy-terminal region, changing the spatial configuration of the protein and leading to the lack of biological activity (Kambadur et al., 1997; McPherron and Lee, 1997; Berry et al., 2002). In the same cattle breed, a nucleotide transversion of $\mathrm{C} \rightarrow \mathrm{A}$ at position 282 of exon 1 is reported, 
which determines a conservative substitution of leucine with phenylalanine (L94F), without any change in biological activity (McPherron and Lee, 1997).

In the Marchigiana breed the nucleotide transversion $\mathrm{G} \rightarrow \mathrm{T}$ at position 874 in exon 3 determines the substitution of the glutamic acid to yield a stop codon (E219X), blocking the translation of the next 245 nucleotides (Cappuccio et al., 1998; Marchitelli et al., 2003). In Charolais and Limousine, the nucleotide transition $\mathrm{C} \rightarrow \mathrm{T}$ at position 610 in exon 2 also leads to the substitution of glutamine to yield a stop codon (Q204X) (Grobet et al., 1998). In these two cases, the lack of myostatin biological activity and consequent increase in muscularity is observed. In Japanese Black cattle the polymorphism $G \rightarrow A$ at position 641 in exon 2 determines the amino acid alteration of asparagine to serine; however, this does not result in a lack of biological activity of the protein (Shibata et al., 2003). Other SNPs were described in exon and intron regions of this gene; although the phenotypic alterations were not described. Other nucleotide substitutions were identified in European breeds, but they do not imply in any changes in the amino acid sequence (Dunner et al., 2003).

Twelve SNPs were identified in the three exons of the myostatin gene in Brazilian buffaloes (Bubalus bubalis), when compared with the Bos taurus sequences, leading to five amino acid substitutions in the protein sequence (Mota et al., 2005).

Brazilian beef cattle is mainly composed of Nellore animals (Bos indicus), which are well adapted to the tropical environment, producing high yields of meat. However, there are no reports available on polymorphisms in the myostatin gene in this breed.

The objective of this study was to analyze the nucleotide sequence of the three exons of the myostatin gene in Nellore cattle, including the noncoding region of exon 3 , aiming to identify polymorphisms in this breed, which could be useful tools for breeding programs.

\section{MATERIAL AND METHODS}

\section{DNA samples}

For DNA extraction, 30 blood samples from Nellore cattle were randomly selected from the routine service in the Laboratório de Bioquímica e Biologia Molecular Animal at Universidade Estadual Paulista, UNESP, Araçatuba campus, State of São Paulo. Samples containing $3 \mathrm{~mL}$ whole blood were collected in siliconized vacuum tubes with sodium citrate. DNA extraction was performed from $700 \mu \mathrm{L}$ whole blood, using the phenol-chloroform protocol described by Sambrook et al. (1989). Quantity and integrity of DNA were analyzed by $2 \%$ agarose gel electrophoresis with ethidium bromide staining.

\section{Polymerase chain reaction}

Two pairs of primers were designed for each exon, 1 and 2 (1AF, 1AR and 2AF, $2 \mathrm{AR}$, respectively) and 6 pairs for exon 3 and the UTR (3AF, 3AR; 3BF, 3BR; 3CF, 3CR; 3DF, 3DR; 3EF, 3ER, and 3FF, 3FR) (Invitrogen Life Technologies, Carlsbad, CA, USA). These primers also amplified some regions of introns 1 and 2. Nucleotide positions for each primer are indicated in Figure 1 and Table 1. 


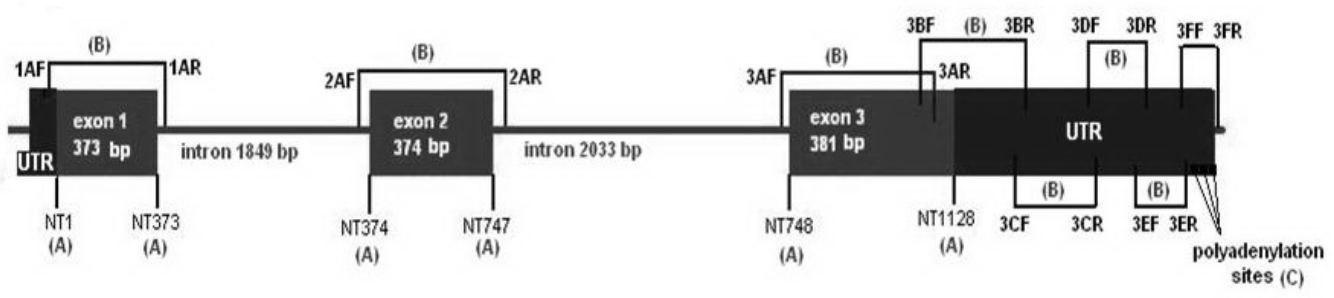

Figure 1. Schematic representation of the bovine myostatin gene (exons, introns and untranslated region - UTR). (A) Gene position of nucleotide (NT) of the translated region of three exons; (B) Localization of 8 pairs of primers (1AF, 1AR; 2AF, 2AR; 3AF, 3AR; 3BF, 3BR; 3CF, 3CR; 3DF, 3DR; 3EF, 3ER; 3FF, 3FR); (C) Polyadenylation sites in exon 3.

Table 1. Gene position of nucleotide (NT) and sequence of nucleotides, length of DNA fragment in base pairs (bp) and annealing temperature (AT) of 8 primer pairs covering three exons and untranslated region of the bovine myostatin gene.

\begin{tabular}{|c|c|c|c|c|c|}
\hline Exon & $\begin{array}{l}\text { Oligonucleotide } \\
\qquad(\mathrm{F} / \mathrm{R})\end{array}$ & Gene position & Sequence $5 ' \rightarrow 3^{\prime}$ & $\begin{array}{l}\text { Length of DNA } \\
\text { fragment (bp) }\end{array}$ & $\mathrm{AT}\left({ }^{\circ} \mathrm{C}\right)$ \\
\hline Exon 1 & $\begin{array}{l}1 \mathrm{AF} \\
1 \mathrm{AR}\end{array}$ & $\begin{array}{c}\text { NT1 }(-98) \\
\text { NT373 }(+123)\end{array}$ & $\begin{array}{l}\text { ggcaggcattaacgtttggc } \\
\text { ttcccetccttacatac }\end{array}$ & 594 & 54 \\
\hline Exon 2 & $\begin{array}{l}2 \mathrm{AF} \\
2 \mathrm{AR}\end{array}$ & $\begin{array}{c}\text { NT374 (-72) } \\
\text { NT747 (+139) }\end{array}$ & $\begin{array}{l}\text { gattgatatggaggtgttcg } \\
\text { agggctaccactgggg }\end{array}$ & 585 & 60 \\
\hline \multirow{6}{*}{$\begin{array}{l}\text { Exon } 3 \\
+ \\
\text { UTR }\end{array}$} & $\begin{array}{l}3 \mathrm{AF} \\
3 \mathrm{AR}\end{array}$ & $\begin{array}{l}\text { NT748 }(-57) \\
\text { NT1088 }\end{array}$ & $\begin{array}{l}\text { cttgaggtaggagagtg } \\
\text { ttcccgtatattatttgtcc }\end{array}$ & 398 & 58 \\
\hline & $\begin{array}{l}3 \mathrm{BF} \\
3 \mathrm{BR}\end{array}$ & $\begin{array}{c}\text { NT999 } \\
\text { NT1128 }(+310)\end{array}$ & $\begin{array}{c}\text { ggttcagccggcccet } \\
\text { tcaccagaagacaaggagaat }\end{array}$ & 439 & 56 \\
\hline & $\begin{array}{l}3 \mathrm{CF} \\
3 \mathrm{CR}\end{array}$ & $\begin{array}{l}\text { NT1128 (+270) } \\
\text { NT1128 (+723) }\end{array}$ & $\begin{array}{l}\text { atgcaggtgaatgaaagc } \\
\text { agacctctaggaaaatga }\end{array}$ & 453 & 56 \\
\hline & $\begin{array}{l}3 \mathrm{DF} \\
3 \mathrm{DR}\end{array}$ & $\begin{array}{c}\text { NT1128 (+675) } \\
\text { NT1128 }(+1080)\end{array}$ & $\begin{array}{l}\text { ggcaatggatgttcttctatag } \\
\text { aagaccactatttaatcaac }\end{array}$ & 405 & 54 \\
\hline & $\begin{array}{l}3 \mathrm{EF} \\
3 \mathrm{ER}\end{array}$ & $\begin{array}{c}\text { NT1128 (+997) } \\
\text { NT1128 (+1239) }\end{array}$ & $\begin{array}{c}\text { attaaggcacaaagacatg } \\
\text { attactaattgagatct }\end{array}$ & 243 & 56 \\
\hline & $\begin{array}{l}3 F F \\
3 F R\end{array}$ & $\begin{array}{l}\text { NT1128 (+1191) } \\
\text { NT1128 }(+1500)\end{array}$ & $\begin{array}{l}\text { atttcaatggtttactgtca } \\
\text { gttgtctttcaaaaaaggtg }\end{array}$ & 309 & 55 \\
\hline
\end{tabular}

F: forward and R: reverse. UTR = untranslated region.

Polymerase chain reaction (PCR) amplifications using the 8 pairs of primers were developed separately. The amplification mix contained: 50 ng genomic DNA, 2 to 4 pmol of each primer (forward and reverse), $2 \mathrm{mM} \mathrm{MgCl}_{2}, 0.2 \mathrm{mM}$ dNTP (deoxyribonucleoside 5'- triphosphates - dATP, dCTP, dGTP, and dTTP), PCR buffer (10 mM Tris-HCl, $\mathrm{pH} 8.0$, and $50 \mathrm{mM} \mathrm{KCl}$ ) (Invitrogen Life Technologies), $1 \mathrm{U}$ Taq DNA polymerase (Invitrogen Life Technologies) and completed with ultra-pure water (Invitrogen Life Technologies). PCR consisted of 5 steps: 1) initial denaturation of double strand at $95^{\circ} \mathrm{C}$ for $3 \mathrm{~min}$, followed by 35 cycles of 2) denaturation at $94^{\circ} \mathrm{C}$ for $1 \mathrm{~min}, 3$ ) primer annealing between $54^{\circ}$ 
and $60^{\circ} \mathrm{C}$ for $\left.1.5 \mathrm{~min}, 4\right)$ extension at $72^{\circ} \mathrm{C}$ for $1 \mathrm{~min}$, and 5) final extension at $72^{\circ} \mathrm{C}$ for $10 \mathrm{~min}$. In every experiment, negative controls were performed containing all reagents except DNA, aiming to avoid contaminations.

Assays were performed in a thermal cycler (PTC- $100^{\mathrm{TM}}$ Programmable Thermal Controller MJ - Research, CA, USA), and the amplicons were analyzed by $2 \%$ agarose horizontal gel electrophoresis. The molecular weight marker 100-bp DNA ladder (Invitrogen Life Technologies) was used in each gel to allow the determination of the amplicon size. Agarose gels were stained with ethidium bromide and visualized under ultraviolet light. After gel photo-documentation, remaining PCR products were purified from free nucleotides and primers with the enzymes EXO-SAP (exonuclease I, shrimp alkaline phosphatase) (Amersham Biociences, Piscataway, NJ, USA) according to the supplier instruction. After the enzymatic treatment, PCR products were submitted to DNA sequencing.

\section{DNA sequencing}

DNA sequencing was performed in an automated DNA analyzer, the MegaBACE ${ }^{\mathrm{TM}}$ 1000 DNA Analysis System (Amersham Biociences). To prepare sequencing reactions, DYEnamic ${ }^{\mathrm{TM}}$ Terminator Cycle Sequencing Kit (Amersham Biociences) was employed, following supplier instructions. The DNA sequence quality was determined by the MegaBACE Sequencing ScoreCard version 2.2 (Amersham Biociences) software; where sequences with quality lower than 90 (index determined by software) were discarded and sequencing reaction was redone.

\section{Sequence alignment}

DNA sequences from the 8 gene fragments generated by PCR were aligned and analyzed using the ClustalW Multiple Alignment (Thompson et al., 1994) software. Nucleotide sequences originated in this study were aligned with cattle myostatin gene sequences existing at GeneBank from Bos taurus (GenBank accession number AB076403) and Bos indicus (GenBank accession number AY794986).

\section{RESULTS}

Myostatin gene polymorphisms were detected by the sequencing of PCR products, generated from 8 regions, covering the three exons and the UTR, in each one of the 30 animals analyzed. There were 5' and 3' (forward and reverse) sequences produced for each fragment, and only the polymorphisms that appeared in at least $10 \%$ of the analyzed animals were classified as SNPs. This approach was adopted in order to exclude technical artifacts originating from mis-incorporation of nucleotides during the PCR procedure.

In exon 1, three polymorphisms were observed, and among those, the polymorphism at nucleotide 76 (NT76) (A/T - heterozygote) implied a conservative nonsynonymous alteration in the amino acid, at position 26 [asparagine $(\mathrm{N})$ to tyrosine $(\mathrm{Y})$ ]. Polymorphisms at NT111 (G/T - heterozygote) and NT267 (A/G - heterozygote or A $\rightarrow \mathrm{G}$ homozygote) resulted in synonymous mutations (Figure 2). 

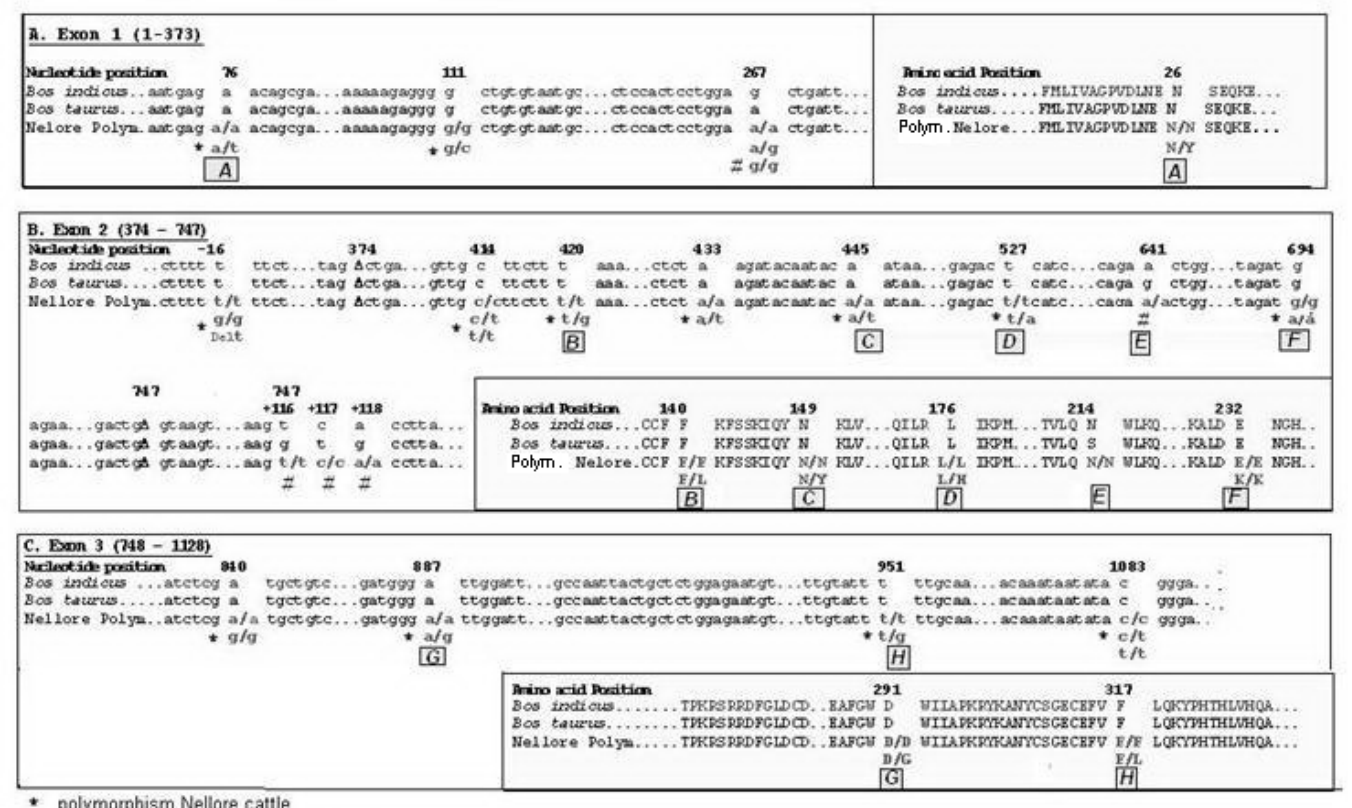

* polymorphism Nellore cattle

\# polymorphism Nellore cattle Bos indicus

Figure 2. Sequence alignments (nucleotide and amino acid) of exons 1, 2 and 3 of Nellore myostatin gene with Bos indicus (AY794986) and Bos taurus (AB076403) sequences and positioning of identified polymorphisms (Polym.) in Nellore cattle. The nucleotide and amino acid polymorphic sites are demonstrated. The capital letters under nucleotide modifications imply amino acid change. Symbol $\Delta$ in exon 2 indicates start and end points of the exon. Del signifies nucleotide deletion. Polymorphisms found in introns $1(-16(374)$ and 2, $747(+116), 747(+117)$ and $747(+118))$ are represented.

Seven polymorphisms were identified in exon 2 , generating synonymous changes in NT414 (C/T - heterozygote) and NT433 (A/T - heterozygote); polymorphisms in NT420 (T/G - heterozygote) and NT445 (A/T - heterozygote) resulted in nonsynonymous conservative alterations at positions 140 and 149 of the protein, implying an amino acid change of phenylalanine $(\mathrm{F})$ to leucine $(\mathrm{L})$ and asparagine $(\mathrm{N})$ to tyrosine $(\mathrm{Y})$, respectively. Polymorphisms in NT527 (T/A - heterozygote), NT641 (G $\rightarrow$ A - homozygote) and NT694 (G $\rightarrow$ A - homozygote) resulted in radical nonsynonymous changes in the amino acid sequence. Polymorphisms at NT527 led to a change of leucine (L) to histidine $(\mathrm{H})$ at position 176, at NT641 an amino acid change of asparagine (N) to serine (S) at position 214, and at NT694 a change of glutamic acid (E) to lysine (K) at position 232 in the amino acid sequence (Figure 2).

Four polymorphisms were identified in exon 3; two of them, at NT840 - A $\rightarrow$ G homozygote and NT1083 - C/T heterozygote or C $\rightarrow$ T homozygote were synonymous. In NT887 (A/G heterozygote), there was a radical nonsynonymous change of aspartic acid (D) to glycine (G) at position 291, and in NT951 (T/G heterozygote) there was a conservative nonsynonymous change of phenylalanine (F) to lysine (L) at position 317 of the amino acid sequence (Figure 2). 
The polymorphic sites found at intron 1 (NT374 -16) were a deletion of T or substitution of T with G. At intron 2, positions NT747 $+116,+117,+118$, nucleotide changes equal to those previously reported in Bos indicus (AY94986) were identified, when compared to Bos taurus (AB076403) (Figure 2).

A total of 37 polymorphic sites were found in the UTR, 24 being of Nellore cattle DNA sequence and 13 the same as Bos indicus DNA sequence previously reported (AY94986) (Figure 3).

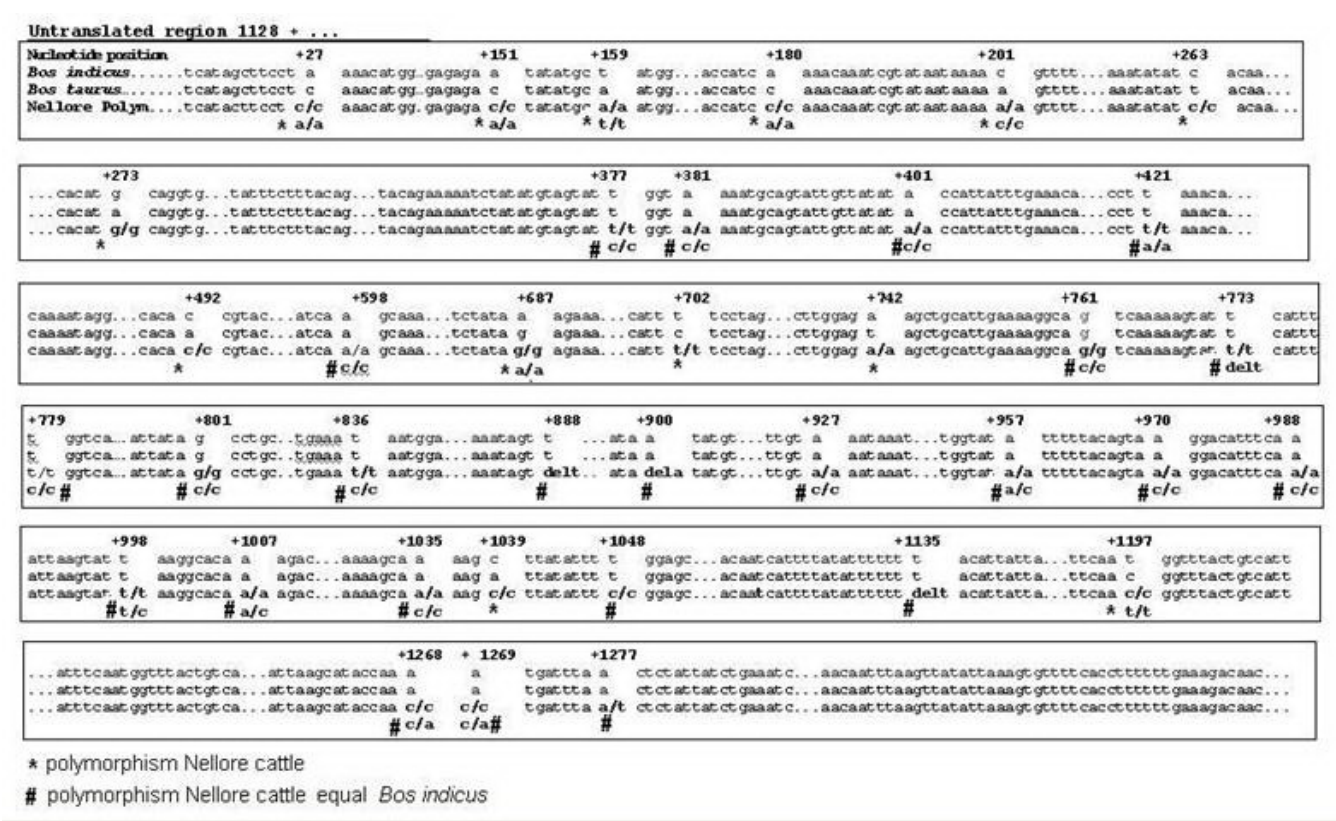

Figure 3. Sequence alignment (nucleotide) of untranslated region of Nellore myostatin gene with Bos indicus (AY794986) and Bos taurus (AB076403) sequences, and positioning of identified polymorphisms (Polym.). The nucleotide polymorphic sites are indicated. Del signifies nucleotide deletion.

\section{DISCUSSION}

High rates of polymorphism have been reported for the myostatin gene in humans (Ferrell et al., 1999) and cattle (Grobet et al., 1998), which was verified in the present study. The high degree of heterogeneity could be related to the high mutation rates specific for this gene, which could be a result of a long history of artificial selection for meat production, favoring the occurrence of new mutations and increasing dramatically the variability of this locus (Grobet et al., 1998; Dunner et al., 2003).

There are at least 6 different types of mutations in the myostatin gene that are related to the double muscling phenotype: NT419 (del7-ins10), NT610 $(\mathrm{C} \rightarrow \mathrm{T})$, NT676 $(\mathrm{G} \rightarrow \mathrm{T})$, NT821 (del11), NT874 $(\mathrm{G} \rightarrow$ T), and NT938 $(\mathrm{G} \rightarrow \mathrm{A})$ (Kambadur et al., 1997; McPherron and 
Lee, 1997; Cappuccio et al., 1998; Grobet et al., 1998); however, in the present study, it was not possible to detect the same polymorphisms in Nellore cattle.

The polymorphism NT641 found in Nellore cattle was previously described in Japanese Black cattle. This polymorphism promoted the conservative substitution of asparagine (N) with serine (S) at amino acid position 214 in exon 2 (Figure 2), and therefore, it did not determine the double muscling phenotype in this breed, due to the position where the substitution occurred, being referred to as an unimportant domain for myostatin biological function (McPherron and Lee, 1997; Shibata et al., 2003).

The polymorphic site at NT267, found in Nellore cattle, was previously reported for some French breeds: Aubrac, Badaize and Salers (Dunner et al., 2003), as well as for Bos indicus (AY94986). Polymorphisms found in NT374 (-16) at intron 1 and in NT414 at exon 2, previously described in European breeds (Asturiana, Rubia, Aubrac, Charolaise, Gasconne, Salers) by Dunner et al. (2003), were also found in Nellore cattle.

Eleven new polymorphisms were identified in the three exons of Nellore breed (Figure 2), with 4 synonymous mutations and 7 nonsynonymous mutations, leading to amino acid changes.

From all polymorphic sites found in introns, exons and UTRs (55), 18 of them were equal to those present in the Bos indicus DNA sequence (AY94986), verifying the Indian origin of these Nellore animals. However, polymorphic sites of Bos taurus were also identified in Nellore animals. Many new polymorphisms were found, indicating the high mutation rate of this gene, mostly in the non-conserved regions.

In summary, we report here the first characterization of the myostatin coding regions of Nellore cattle and the identification of 14 nucleotide changes and 8 alterations in the presumed myostatin protein sequence as compared to non-double-muscled bovine sequences. From an applied point of view, the identification of the myostatin gene polymorphisms in Nellore cattle, after validation and association with meat production parameters, can contribute to the establishment of a useful diagnostic screening system allowing for marker assisted selection.

\section{ACKNOWLEDGMENTS}

We thank UNESP, Botucatu, SP, and Araçatuba, SP, and the Brazilian agency CAPES for financial support.

\section{REFERENCES}

Berry C, Thomas M, Langley B, Sharma M, et al. (2002). Single cysteine to tyrosine transition inactivates the growth inhibitory function of Piedmontese myostatin. Am. J. Physiol. Cell Physiol. 283: C135-C141.

Cappuccio I, Marchitelli C, Serracchioli A, Nardone A, et al. (1998). A G-T transversion introduces a stop codon at the $m h$ locus in hypertrophy Marchigiana beef subjects. Anim. Genet. 29: 51.

Charlier C, Coppieters W, Farnir F, Grobet L, et al. (1995). The $m h$ gene causing double-muscling in cattle maps to bovine chromosome 2. Mamm. Genome 6: 788-792.

Dunner S, Miranda ME, Amigues Y, Canon J, et al. (2003). Haplotype diversity of the myostatin gene among beef cattle breeds. Genet. Sel. Evol. 35: 103-118.

Ferrell RE, Conte V, Lawrence EC, Roth SM, et al. (1999). Frequent sequence variation in the human myostatin (GDF8) gene as a marker for analysis of muscle-related phenotypes. Genomics 62: 203-207.

Grobet L, Martin LJ, Poncelet D, Pirottin D, et al. (1997). A deletion in the bovine myostatin gene causes the doublemuscled phenotype in cattle. Nat. Genet. 17: 71-74. 
Grobet L, Poncelet D, Royo LJ, Brouwers B, et al. (1998). Molecular definition of an allelic series of mutations disrupting the myostatin function and causing double-muscling in cattle. Mamm. Genome 9: 210-213.

Jeanplong F, Sharma M, Somers WG, Bass JJ, et al. (2001). Genomic organization and neonatal expression of the bovine myostatin gene. Mol. Cell Biochem. 220: 31-37.

Kambadur R, Sharma M, Smith TP and Bass JJ (1997). Mutations in myostatin (GDF8) in double-muscled Belgian Blue and Piedmontese cattle. Genome Res. 7: 910-916.

Marchitelli C, Savarese MC, Crisa A, Nardone A, et al. (2003). Double muscling in Marchigiana beef breed is caused by a stop codon in the third exon of myostatin gene. Mamm. Genome 14:392-395.

McPherron AC and Lee SJ (1997). Double muscling in cattle due to mutations in the myostatin gene. Proc. Natl. Acad. Sci U. S. A. 94: 12457-12461.

Mota LSLS, Curi RA, Palmieri DA and Borges AS (2005). Sequence characterization of coding regions of the myostatin gene (GDF8) from Brazilian Murrah buffaloes (Bubalus bubalis) and comparison with the Bos taurus sequence. Genet. Mol. Biol. 29: 79-82.

Sambrook J, Fritsch EF and Maniats T (1989). Molecular Cloning: a Laboratory Manual. 2nd edn. Cold Spring Harbor Laboratory Press, New York.

Shibata M, Ohshima K, Kojima T, Muramoto T, et al. (2003). Nucleotide sequence of myostatin gene and its developmental expression in skeletal muscles of Japanese Black cattle. Anim. Sci. J. 74: 383-390.

Smith TP, Lopez-Corrales NL, Kappes SM and Sonstegard TS (1997). Myostatin maps to the interval containing the bovine $\mathrm{mh}$ locus. Mamm. Genome 8: 742-744.

Thompson JD, Higgins DG and Gibson TJ (1994). CLUSTAL W: improving the sensitivity of progressive multiple sequence alignment through sequence weighting, position-specific gap penalties and weight matrix choice. Nucleic Acids Res. 22: 4673-4680. 